\title{
The Insect Frontal Ganglion and Stomatogastric Pattern Generator Networks
}

\author{
Amir Ayali \\ Department of Zoology, Faculty of Life Sciences, Tel Aviv University, Tel Aviv, Israel
}

\section{Key Words}

Central pattern generator - Feeding behavior · Frontal ganglion · Locust - Manduca sexta · Molting •

Neuromodulation - Stomatogastric nervous system

\begin{abstract}
Insect neural networks have been widely and successfully employed as model systems in the study of the neural basis of behavior. The insect frontal ganglion is a principal part of the stomatogastric nervous system and is found in most insect orders. The frontal ganglion constitutes a major source of innervation to foregut muscles and plays a key role in the control of foregut movements. Following a brief description of the anatomy and development of the system in different insect groups, this review presents the current knowledge of the way neural networks in the insect frontal ganglion generate and control behavior. The frontal ganglion is instrumental in two distinct and fundamental insect behaviors: feeding and molting. Central pattern-generating circuit(s) within the
\end{abstract}

I gratefully acknowledge support from the USA-Israel Binational Science Foundation (BSF 9800456) and the Israel Science Foundation (ISF 410/02).

\section{KARGER}

Fax +41613061234

E-Mail karger@karger.ch

www.karger.com
(C) 2004 S. Karger AG, Basel

1424-862X/04/0132-0020\$21.00/0

Accessible online at:

www. karger.com/nsg frontal ganglion generates foregut rhythmic motor patterns. The frontal ganglion networks can be modulated in-vitro by several neuromodulators to generate a variety of motor outputs. Chemical modulation as well as sensory input from the gut and input from other neural centers enable the frontal ganglion to induce foregut rhythmic patterns under different physiological conditions. Frontal ganglion neurons themselves are also an important source of neurosecretion. The neurosecretory material from the frontal ganglion can control and modulate motor patterns of muscles of the alimentary canal. The current and potential future importance of the insect stomatogastric nervous system and frontal ganglion in the study of the neural mechanisms of behavior are discussed.

Copyright @ 2004 S. Karger AG, Basel

\section{Introduction}

The insect nervous system has been widely and successfully employed as a model system in the study of the neural basis of behavior [e.g. 1-4]. Hoyle [1] has noted the outstanding importance of the insect model system for a comparative neurophysiological approach to neural net-

Amir Ayali

Department of Zoology

Faculty of Life Sciences, Tel Aviv University

Tel Aviv 69978 (Israel)

Tel. +972 3640 9820, Fax +972 3640 9403, E-Mail ayali@post.tau.ac.il 
work analysis (as in this special issue of Neurosignals). The considerable potential of insect models arises, on the one hand, from the great accessibility and simplicity of the insect nervous and neuroendocrine systems. Both systems have been amply studied and are well characterized in insects [4-6]. On the other hand, insects are capable of demonstrating complex and very carefully controlled behavioral processes that are relatively easily studied in the laboratory. The many similarities and common principles shared by the nervous systems of simple and higher organisms are by now a well-known and widely accepted fact [e.g. 7, 8].

A second key aspect of research on insect neural networks is that insights into the basis of insect behavior have important practical consequences. The arsenal of safe and cost-effective insecticides is shrinking for various reasons (e.g. insecticide resistance and unacceptable side effects). New strategies for insect pest management, more effective and above all ecologically safe ones, pose an ongoing challenge. Detailed knowledge of the neural and neuroendocrine mechanisms underlying insect behaviors can serve the urgent need to define alternatives targets.

The insect stomatogastric nervous system (also referred to as the enteric or stomodeal nervous system in early work) is present, in some form or another, in all known insect species $[9,10]$. It serves to innervate the anterior parts of the insect digestive tract [11-21]. Ample work and very rich literature has been dedicated to this system in Crustacea ([22], see also the article by Hooper, pp. 50-69, in the present issue). Mainly due to its small cell number and (relatively) simple behavioral output, the stomatogastric nervous system in lobsters and crabs has served for several decades as a leading model in the study of the neural control of rhythmic behavior. Our knowledge of the equivalent insect system (the question of homology is an important one but beyond the scope of the current work) is lagging far behind. Furthermore, as the stomatogastric nervous system is present in all higher invertebrates, starting from annelids [23-26], it offers a very suitable and attractive case for evolutionary or comparative investigations of the insect nervous system.

This review summarizes the present knowledge on the insect stomatogastric nervous system and, specifically, one of its principle components, the frontal ganglion (FG). Following a short description of the anatomy of the system in different insect groups, I briefly present aspects of the development of the insect stomatogastric nervous system. Both issues have been covered previously in detailed reviews (see below). The current paper focuses on the neural basis for the control of two fundamental behav- iors in an insect's life: feeding and molting. As will be described, the stomatogastric nervous system, and specifically the FG, plays a critical role in both behaviors. The current state of our knowledge of the neural networks that generate foregut rhythmic movements will be presented. Finally, the importance of neuromodulation and neurosecretion in the insect stomatogastric nervous system will be discussed.

\section{The Insect Stomatogastric Nervous System: Gross Anatomy and Development}

The anatomy of the stomatogastric nervous system in insects reflects its function and thus varies mainly according to the mode of feeding of the species. As would be expected, the system is generally reduced in liquid-feeding insects, where foregut movement is mainly myogenic $[27,28]$ but is more evident in insects feeding on solid foodstuffs, where movements of the foregut are more complex, i.e. both myogenic and neurogenic [29-32]. In the case of holometabolous insects, where the mode of feeding is closely tied to the insect's developmental stadium, we should also expect some changes in the stomatogastric nervous system along with the insect's ontogeny. According to Snodgrass [33], 'it is impossible to give a general description applicable to all its (the stomatogastric nervous system) numerous variations in different insects'.

Detailed morphological studies of the stomatogastric nervous system of specific insect groups were first provided by Orlov [11,34] for the larvae of the beetle Oryctes. An anatomical description was also given by Willey [12] for Periplaneta americana and other Blattaria. Dando et al. [16] first described the system in Schistocerca gregaria, and Kirby et al. [20, 21] in Acheta domesticus. Investigations of the stomatogastric nervous system of lepidopterous insects (Manduca sexta) were provided by Borg et al. [35] and Bell et al. [36]. These and others were reviewed in detail by Penzlin [10] and Chapman [37]. More recently, the stomatogastric nervous system in some Dipteran species [38-40] and in Apis mellifera [41] was also described.

In all the studied insects the stomatogastric nervous system consists of a series of small ganglia that are closely associated with the brain, the corpora cardiaca and corpora allata and the anterior portion of the gut (fig. 1). The FG is a principal component of the stomatogastric system in most insect orders [10,37], accordingly, this ganglion has attracted much research. The best detailed account of 


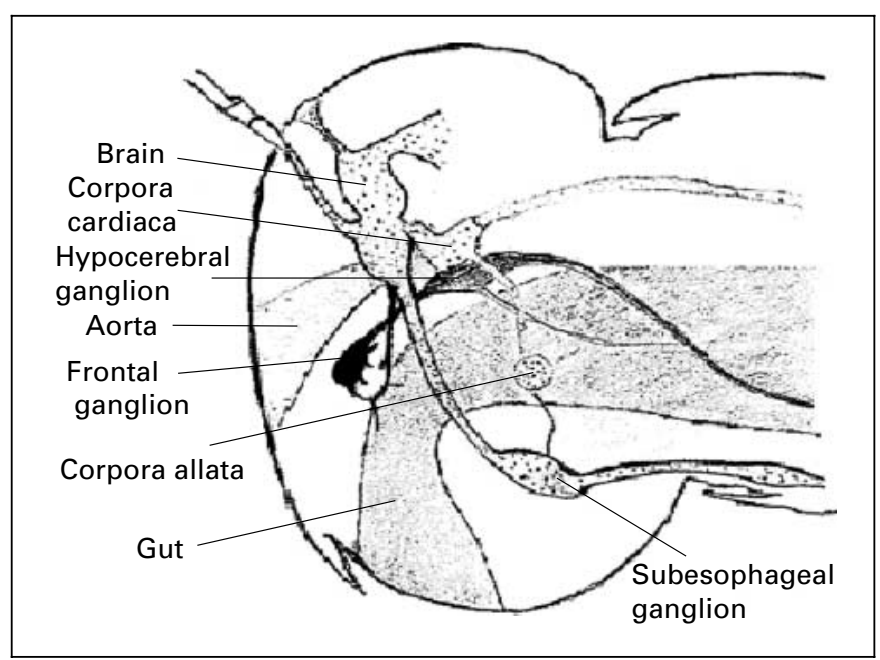

Fig. 1. Sectional diagram of an Orthopteran insect head, showing the position of the cephalic stomatogastric ganglia, the frontal and hypocerebral ganglia (black) relative to the major neural and endocrine centers. Modified from Ayali et al. [45].

the cellular structure of the insect FG was given for P. americana [42-44] and Acheta [20, 21].

Two insect preparations which, in recent years, have been at the focus of neurophysiological studies of the stomatogastric nervous system will be discussed in greater detail below. Ample work on the different Orthopteran species has set the ground for recent investigations of the FG of the desert locust $S$. gregaria [45-47], and recent studies on the tobacco hornworm $M$. sexta $[48,49]$ are based on previous work on lepidopterous insects.

In locusts, the FG lies in the forehead, on the dorsal side of the pharynx, in front of the brain. It is connected to the tritocerebrum of the brain by the paired frontal connectives (fig. 2a). Posteriorly, a recurrent nerve passes from the FG along the pharynx, under the brain and over the dorsal side of the esophagus. It branches onto the dilator and constrictor muscles of the pharynx, and ends in the hypocerebral ganglion which is closely associated with the corpora cardiaca. Additional three pairs of efferent nerves - the anterior (APN), median (MPN) and posterior pharyngeal nerves (PPN) - branch onto the dilator muscles of the gut in a rostrum to caudal order, making the FG the major source of foregut muscles innervation (fig. 2a). The median recurrent nerve gives rise to paired lateral esophageal nerves, which innervate the more posterior muscles of the esophagus and terminate on the crop in paired ingluvial ganglia. The FG is encased by a neural lamella. It is characterized by a central neuropil surrounded dorsally and laterally by a single or double layer of neurons [see figure 1 in 45]. The cell bodies are 25$50 \mu \mathrm{m}$ in diameter. Their number is estimated to be about 100 , depending on the exact methods used $[18,19]$.

The FG in both larval and adult Manduca is connected to the tritocerebrum by the paired frontal connectives (fig. 2b). Two additional nerves exit the Manduca ganglion; a single recurrent nerve that runs posteriorly from the FG to innervate the muscles of the pharynx and esophagus, and an anteriorly directed frontal nerve which innervates the buccal musculature. Unlike the locust, the Manduca stomatogastric nervous system does not feature a hypocerebral ganglion after the embryonic stage [48]. During adult development there is much rearrangement of foregut musculature accompanying the formation of the cibarium. In adult moths, the FG innervates the muscles of the cibarial pump. The frontal nerve innervates most of the pump dilators and the recurrent nerve innervates the pump compressors (fig. 2b); [49]. In Manduca fifth-instar larvae and adults, the FG is $160 \mu \mathrm{m}$ in diameter and contains about 35 neurons, arranged in a single layer. The neurons range in diameter from about 20 to $45 \mu \mathrm{m}$, and a number of them have been identified in both larvae and adults [48-50].

A growing number of studies present the insect stomatogastric nervous system as a model for nervous system development. Most research on insect stomatogastric system development employed either $M$. sexta [51-55], or Drosophila melanogaster [56-58]. Ganfornina et al. [59] focused on the embryonic development of the locust stomatogastric nervous system. Using a number of specific molecular markers, these authors studied morphogenesis and some aspects of neuronal differentiation in the locust system. In his thorough review, Hartenstein [60] reports that the insect stomatogastric nervous system is derived from a small neuroectodermal placode located in the foregut. All cells within this placode give rise to neural cells whose precursors migrate and finally re-aggregate to form the different stomatogastric system ganglia.

\section{Physiological Role of the Insect Stomatogastric Nervous System and Frontal Ganglion}

In his review article, dedicated primarily to the structure of the stomatogastric nervous system, Penzlin [10] writes: 'Much more experimental work is necessary to gain a better consolidated insight into the control function of the stomatogastric nervous system'. More than a de- 


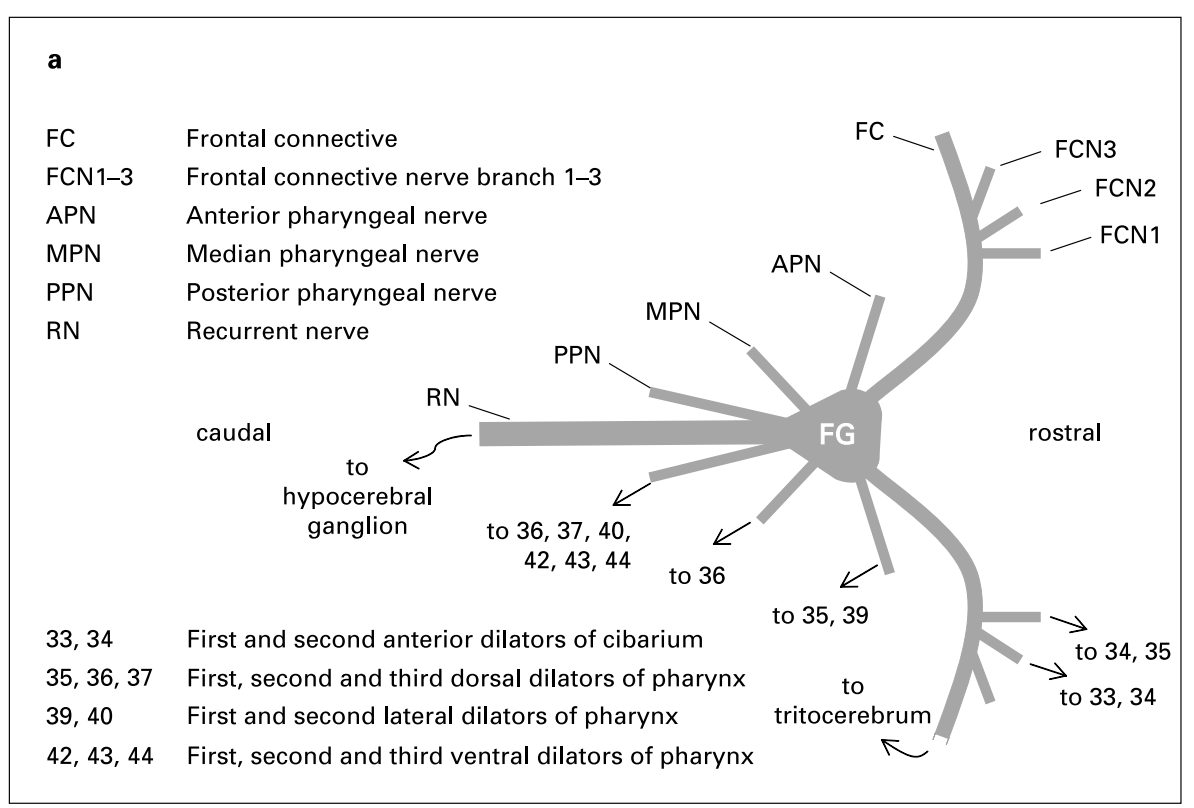

Fig. 2. A schematic drawing of the $F G$ of the locust (a) and Manduca (b). In each panel, the upper half shows the ganglion nerves and the lower half the muscles they innervate. Caudal and rostral sides are also indicated.

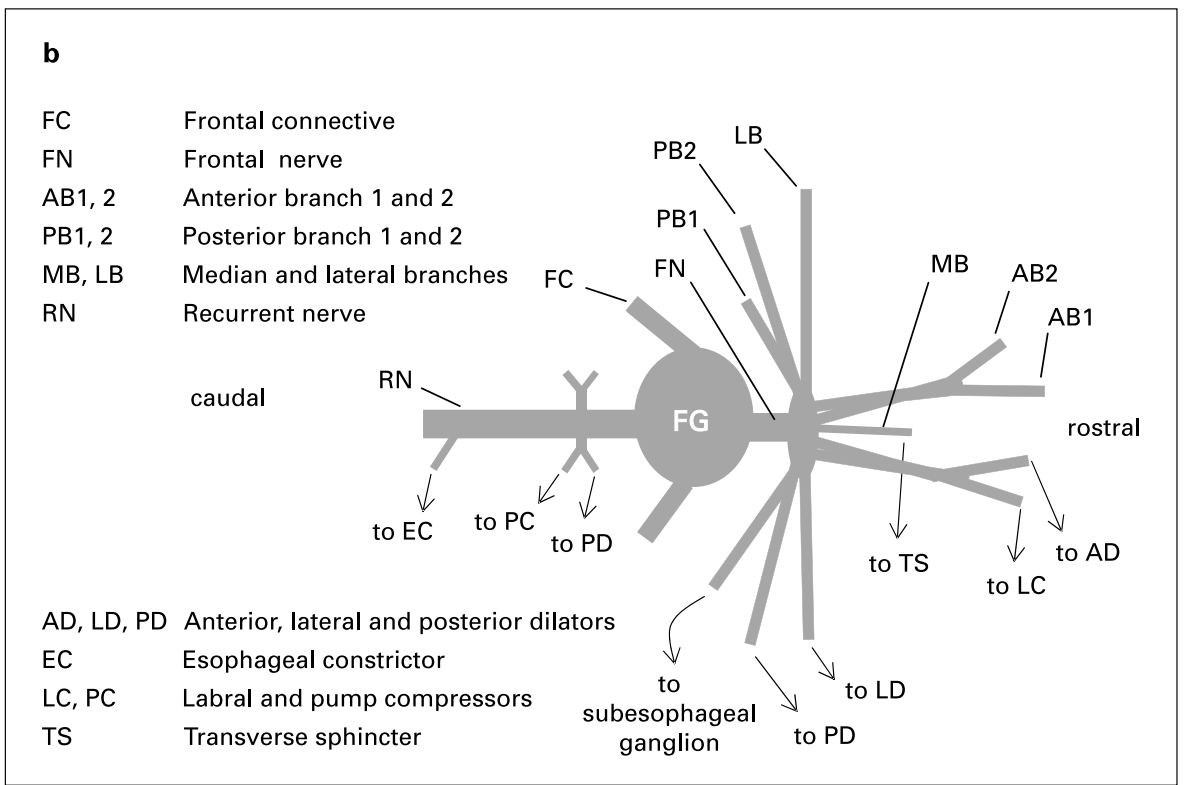

cade later, in The Neurobiology of an Insect Brain, Burrows [2] made the following comment: '... virtually nothing is known of their (the stomatogastric or stomodeal ganglia) physiological actions, in stark contrast to their counterparts in crustacea.'

In spite of the above statements, the function of the insect stomatogastric nervous system has been the focus of many studies for more than 100 years [61, 62]. Most of these studies, however, examined the effects of ablating the FG on the subsequent behavior and development of the insect [10, and references therein].

Roussel [63] reported a role for the FG in the control of cardiac rhythm in Locusta migratoria. These findings were repeated in the sweet potato hornworm, Agrius convolvuli, where the FG was also found to control heartbeat $[64,65]$. This control is exerted via a pair of anterior cardiac nerves that branch off the FG visceral nerve to innervate the dorsal vessel. 
Most previous results have indicated that the FG is instrumental in the processes of growth, water balance and molting [e.g. 66-80]. These findings have been partially supported by recent neurophysiological work which has concentrated on the role of the FG in the control of two fundamental behaviors in the life of insects, feeding and molting [45-50].

\section{The Role of the Frontal Ganglion in the Control of}

Feeding-Related Behavior

Frontal ganglionectomy caused a decrease in feeding activity and food intake in S. gregaria [30, 67, 69], L. migratoria [72], Gryllus bimaculatus [68] and $P$. americana $[73,81,82]$. Food was reported to accumulate in the foregut, and fecal output was markedly reduced [30, and references therein]. Similar results were reported in Lepidoptera, including adult Heliothis zea [78] and M. sexta larvae [79]. Overall, from these multiple studies, one can deduce that the insect FG is instrumental in passing food through the foregut and in crop emptying.

The larval Manduca gut is constantly active. The FG neurons were found to innervate all the larval foregut muscles and the ganglion was reported to be both necessary and sufficient for producing the motor patterns of the foregut [48]. Two types of rhythmic foregut movements and, accordingly, two FG rhythmic motor patterns were described in fifth-instar larvae. The first are posteriorly directed waves of foregut peristalsis, which are generated by phase shifts between rhythmic bursts of activity in anterior and posterior constrictor muscles (fig. 3a). The second type of pattern is characterized by synchronous constriction of muscles along the entire esophageal region. The latter motor pattern was reported to be correlated with accumulation of food within the crop [48]. Presumably it serves to pack the food particles and prevent food from reverting from the crop. In both the described rhythmic patterns, buccal constrictor activity preceded esophageal constrictors.

In contrast to the larvae of most Lepidoptera, locusts are generalist feeders, consuming a wide variety of foods of different composition and form. This wide range, together with the more complex morphological structure of their foregut (in comparison to the Manduca larvae), has led to more complex foregut peristaltic behavior in locusts. Rhythmic activity is not always demonstrated by the locust foregut muscles [46]. Most interestingly, as is the case in the Manduca larvae, the intact locust shows two types of FG motor patterns [46]. However, in the locust only one of these patterns could be related to feeding behavior: a rhythmic motor pattern, consisting of bursts of action potentials recorded on the different motor nerves, which is consistent with a rostrum-to-caudal peristalsis wave in foregut muscles (fig. 3b). This 'food passage' behavior can be recorded from the FG nerves in association with the beginning of a feeding bout. The rhythm increases in cycle frequency as food accumulates in the foregut and crop, and practically stops as soon as the locust gut is full [46]. Between meals, the FG pattern is often totally inhibited; in other cases, it demonstrates a second pattern, which is characterized by full synchronization between bursts of action potentials recorded on the different motor nerves, and both between the FG and the ongoing ventilation motor pattern of the locust [46]. It thus appears that gut movements may also participate in ventilation, probably as a means to help with hemolymph circulation.

Unlike the case of the larval moth, and more similar to the locust, the adult Manduca cibarial pump motor program is only displayed during feeding [49]. Unless the moth is feeding, the muscles of the cibarial pump are silent. The FG activity pattern that generates rhythmic pumping movements in the moth's cibarium is initiated by chemical stimulus to the proboscis of the moth.

Much work is still needed in order to elucidate the role of the FG neural networks in insect feeding-related behavior. As is apparent from the rather limited neurophysiological data available, new insights could be gained by comparing the stomatogastric nervous system in the locust and moth preparations and in the different developmental stages of the holometabola.

\section{The Role of the Frontal Ganglion in the Control of Molt-Related Behavior}

As already mentioned, in addition to feeding, the foregut and insect stomatogastric nervous system play a critical role in at least one other aspect of insect life: the molt. A molting insect displays a stereotypical set of behaviors that culminate in the shedding of the old cuticle at ecdysis. Ecdysial behavior has been extensively characterized in crickets [83, 84], locusts [85-87] and moths [88-91]. In all these insects, as the molt approaches, the insect ceases all feeding-related activity and searches for a suitable site for ecdysis. For example, both S. gregaria and Manduca larvae stop feeding and become quiescent approximately 24-36 $\mathrm{h}$ before ecdysis [50, 87, 92]. This is part of a preparatory or pre-ecdysis phase, which includes motor patterns that are aimed at loosening and eventually splitting the old cuticle. Next, the insect extracts itself from its old cuticle, followed by an expansion period, during which the new cuticle is stretched and shaped and the wings are expanded and folded. 
Fig. 3. FG feeding- and molting-related motor patterns in Manduca (a) and the locust $S$. gregaria $(\mathbf{b})$. a The motor pattern recorded from the adult moth cibarial and our swallowing pump compressor (large units) and dilator muscles during feeding. Data are courtesy of CI Miles. b Simultaneous extracellular recordings of locust FG frontal connective (FC) and median pharyngeal nerves (MPN) during feeding and air swallowing behavior (lower trace). The boxed areas are shown in faster sweep speed on the right.
Feeding

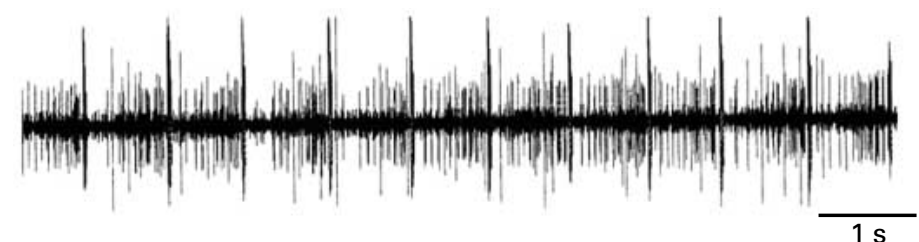

Molting

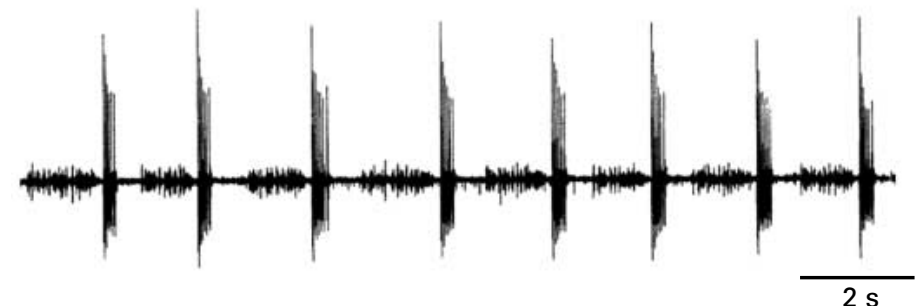

b
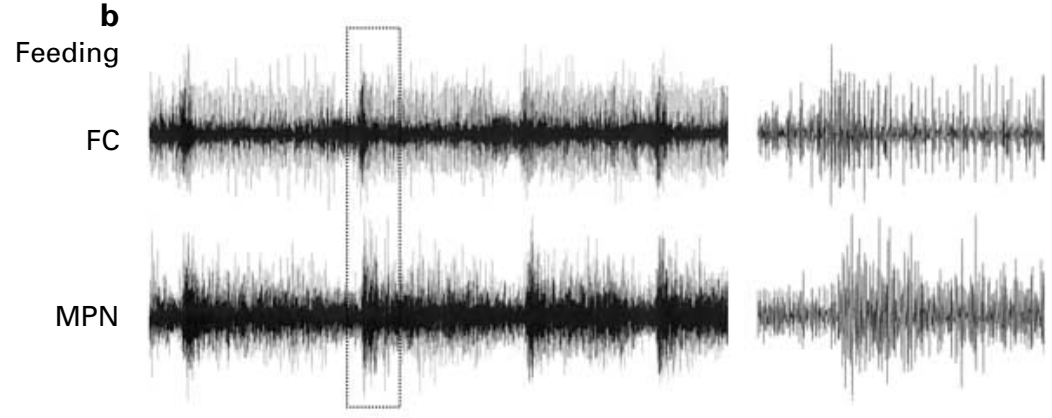

$\overline{5 s}$

$50 \overline{\mathrm{ms}}$

Molting

FC

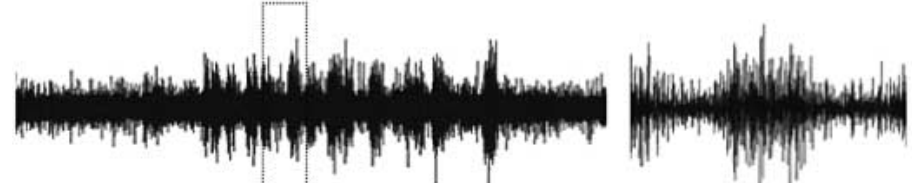

MPN

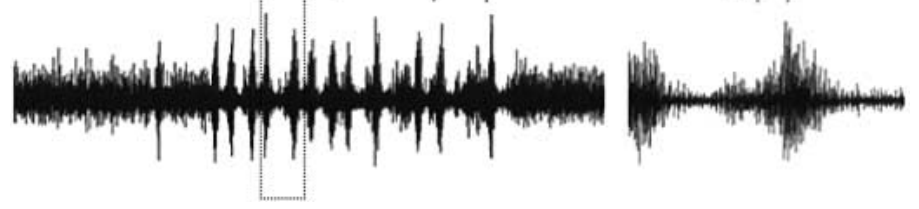

Hence, there are two stages during ecdysis in which the insect needs to exert pressure on the body wall [88]. The first is during rupture of the old cuticle, the second when expanding the new cuticle and wings after emergence. The principal mechanism for doing this is by filling the gut with air. De Bellesme [93] was the first to show that the pronounced enlargement of freshly emerged dragonflies was accomplished by internal air pressure built up in the digestive tract [18]. Since then, air swallowing during ecdysis has been reported in a number of different insects $[49,76,85,88,94]$. The FG was reported to be important for this behavior in several species $[14,15,49,50,66,71$, 75-77]. 
Hughes [74, 75] reported that the success of the imaginal ecdysis of the desert locust depends on inflation of the gut with air. The dynamics of the air-swallowing motor program during the imaginal ecdysis was monitored by electromyogram (EMG) recordings made from foregut dilator (extrinsic) muscles [74, 75]. Elliot [95] accompanied the EMG recordings during the course of the locust molt by intracellular recordings from a small number of motor neurons in the FG, supporting the fact that the ganglion is indeed the source of the molt-related foregut motor pattern [95]. Frontal ganglionectomy abolished air swallowing immediately [74]. In the cricket, Carlson and O'Gara [76] have also described the FG's exclusive control over air-swallowing motor patterns and its importance for a successful molt. Ayali et al. (unpublished results) have recently confirmed these findings by testing the effects of ablating the ganglion of fifth-instar larval locusts, $48 \mathrm{~h}$ before the imaginal molt, on the probability of successful ecdysis. One hundred percent of the experimental animals $(\mathrm{n}=8)$ failed to escape the old cuticle and died during the molt. In contrast, all sham-operated animals $(n=8)$ molted successfully.

Zilberstein and Ayali [46] report a strong interaction between the locust FG and ventilation pattern generator circuits during ecdysis. Throughout the molt process, the FG and ventilatory patterns are totally synchronized, except for the very short period when air-swallowing behavior is activated. During air swallowing, a different pattern emerges that resembles the feeding-related pattern in many aspects (fig. 3b). This uncoupling of the ventilation and FG rhythms could be mimicked by experimental manipulation [46].

Air swallowing was also reported in Lepidoptera. Bell [77] suggested that the FG also plays a role in $M$. sexta eclosion, i.e. ecdysis to the adult stage. The FG was involved in swallowing air at the time of eclosion; frontal ganglionectomy abolished air swallowing immediately, leading to defects in eclosion and in expansion of the wings.

Recent work on $M$. sexta has revealed that the FG plays a critical role in the successful completion of both larval [50] and adult molts [49]. At both stages, the FG controls a foregut motor pattern that is used to remove molting fluids from the space between the old and new cuticle prior to ecdysis. Cornell and Pan [96] were the first to suggest that the gut played a role in the removal of molting fluids. At adult ecdysis, or eclosion, removing the FG resulted in difficulty or failure to shed the old cuticle [49]. The FG is activated about $6 \mathrm{~h}$ before the adult moth emerges from the pupal case. The crop initially fills with molting fluid, then air. After eclosion, as the moth hangs in a position to expand its wings, the FG is again activated, producing a distinct air-swallowing motor pattern that lasts about $90 \mathrm{~s}$ (fig. 3a). During this period, the wings visibly expand. Miles and Booker [49] report that the few ganglionectomized individuals that successfully emerged from the pupal cuticle were unable to expand their wings. The motor pattern recorded from the FG at the time of eclosion is similar to that displayed during feeding (fig. 3) [49].

It is interesting to note that in aquatic arthropods (Crustaceans) the stomatogastric nervous system probably plays an equally important role in swallowing fluids in order to split the old cuticle. This has as yet not been investigated, though it was implied in many reports [e.g. 97-100])

\section{Stomatogastric Neural Circuits}

Electrophysiological studies of the stomatogastric nervous system of insects have been very rare. Möhl [32] was the first to conduct investigations of neural activity in the insect system. His work on $A$. domesticus was followed by Hertel [101], who studied the stomatogastric nervous system of $P$. americana. The latter described spontaneous nervous activity in the caudal parts of the system, most of which could be traced to the FG [101, 102]. As was also later confirmed by Pandey and Habibulla [103], spontaneous neuronal activity could be recorded from an isolated FG in vitro. Hertel and Penzlin [104] demonstrated spontaneous rhythmic burst activity in the stomatogastric nervous system of $P$. americana and Blaberus craniifer. Again, these authors suggested that the rhythm is generated in the FG and from there disseminates throughout the stomatogastric system. However, no physiological function could be assigned to this activity [10].

More recent reports for both M. sexta [48] and S. gregaria [45] have confirmed the early work and established the presence of a central pattern-generating circuit in the insect FG. The larval Manduca ganglion was spontaneously active and produced a bursting firing pattern in the total absence of descending or sensory inputs [48] (fig. 4a). Interestingly, the pattern demonstrated by an in vitro fully isolated preparation resembled that recorded prior to its isolation (characterized by phase shifts between rhythmic bursts recorded from the different efferent nerves, or a fully synchronized bursting pattern (Miles, pers. commun.).

A completely isolated in vitro locust $\mathrm{FG}$ also generated a robust and consistent spontaneous rhythmic motor pattern that could last for many hours (fig. 4b) [45]. The in 
Fig. 4. a Simultaneous recordings from the frontal nerve $(\mathrm{FN})$, recurrent nerve $(\mathrm{RN})$, and frontal connective (FC) in a fully isolated FG dissected from a larvae $M$. sexta. b Simultaneous recordings from the frontal connective (FC), median and posterior pharyngeal nerves (MPN and PPN, respectively) in a fully isolated locust FG in vitro. The panels on the right show 1 burst of activity played at a higher sweep speed to reveal phase relations between different members of the FG central pattern generator.

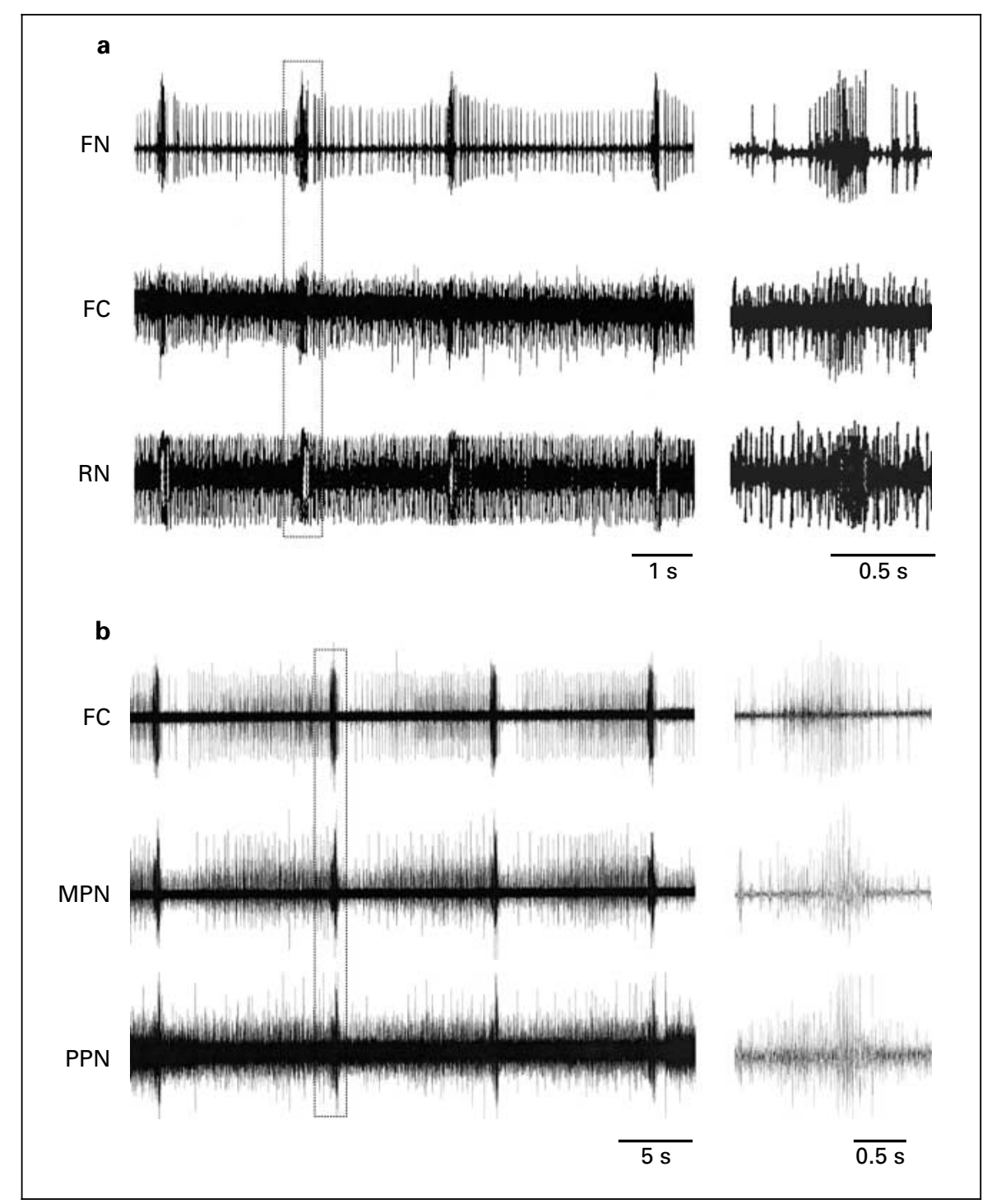

vitro pattern was found to be independent of the donor locust's physiological or developmental stage. It was characterized by multi-unit bursts of action potentials that could be recorded from the various FG motor nerves. Ayali et al. [45] have defined the locust FG rhythmic pattern in vitro as fictive feeding-related or 'food passage' behavior, based on analyzing the temporal delineation of bursts of action potentials recorded on the different motor nerves. Considering the muscles innervated by these nerves, the pattern was consistent with a rostrum-to-caudal peristalsis wave in foregut muscles. Interestingly, in another closely related Orthopteran, the cricket Teleogryllus oceanicus, an isolated FG in vitro was reported to generate rhythmic activity only for $1 \mathrm{~h}$ [76]. Furthermore, in vitro rhythmic activity was exhibited only if the ganglion was dissected out of a molting insect and was characterized by a normal air-swallowing frequency [76].

The locust FG contains around 100 neurons [105], in between the numbers reported for the ganglion of other Orthoptera, such as the cockroach (circa 80 neurons [106]) and the cricket (150 neurons [21]). Are all these neurons members of the pattern-generating network(s)? In most of the central pattern-generating systems investigated, the pattern-generating circuit consists of interneurons, though in some preparations the motor neurons 
themselves participate in generating the rhythm (e.g. the stomatogastric nervous system of Crustacea [107, and references therein]). Kirby et al. [21] suggest that no more than $25 \%$ of the neurons in the FG of $A$. domesticus are interneurons. Aubele and Klemm [19] described 19 neurons located in the locust FG that send their axons to innervate foregut muscles via the frontal connectives and their branches. Similar numbers of small-size neurons (motor neurons) were also reported by Elliott [95]. The rather limited number of rhythmic units included in FG nerve recordings [45], and some preliminary intracellular survey of the ganglion neurons in which the majority of cells proved to be either silent or tonically active (Ayali, unpublished results), are both consistent with the idea that only a relatively small number of the ganglion neurons take part in the FG rhythmic motor pattern. Hertel and Penzlin [104] suggested that the FG spontaneous rhythmic activity in $P$. americana is generated within the ganglion's neuropil in a pair of neurons whose cell bodies are located outside the ganglion, in the protocerebrum. These neurons send their axons to the FG via the nervous connectives.

Our knowledge of the neuronal characteristics or the cellular properties of members of the insect FG neural circuit is limited. In Manduca, only a few of the 35 FG neurons have been explored, using intracellular pipette recordings [48-50]. A number of motor neurons have been identified by correlating their spiking activity with specific muscle excitatory junction potentials. Nothing, however, is known on the synaptic connections between the network members and on their role in generating the rhythmic pattern. The locust FG has proved to be a challenging system for intracellular analysis [45, 95]. However, the limited intracellular recordings made from locust ganglion neurons demonstrate the presence of some properties which are considered to be important for central pattern generation, such as bursting, plateau potentials and post-inhibitory rebound. Recently, Shefi et al. [108] developed a culture preparation of dissociated locust FG neurons. Intracellular recordings from unidentified isolated FG neurons in culture just as they started to regenerate their neuronal processes, also revealed some of the neurons' endogenous properties, such as spontaneous firing and post-inhibitory rebound (Ayali, unpublished results). Extracellular recordings from two-dimensional networks in cultures of FG neurons revealed rhythmic bursting (Ayali et al., unpublished results).

Some information on the synaptic properties of the FG central pattern generator networks can be gained from sporadic evidence regarding effects of cholinergic agonists and antagonists on the insect FG's electrical activity ([104, 109, 110]; Ayali and Dekel, unpublished results). Acetylcholine is an important transmitter in insects. It has also been reported to be a neurotransmitter in the stomatogastric nervous system of the earthworm [25] as well as in Crustaceans [111-113]. Acetylcholine and nicotine showed dose-dependent stimulation of the FG rhythm in $P$. americana [104]. Hertel et al. [110] reported on dosedependent effects of different organophosphorous insecticides on spontaneous burst frequency of isolated ganglia. Increasing concentrations resulted in shortening of the inter-burst intervals, up to total loss of rhythmicity. Similar results were obtained in $S$. gregaria by bath application of the acetylcholinesterase inhibitor paraoxon to a rhythmically active, isolated FG in vitro (fig. 5; Ayali and Dekel, unpublished results). Penzlin [10] reviewed evidence of high acetylcholinesterase activity in the neuropil of the FG in P. americana. However, the cockroach stomatogastric nervous system ganglion cells could not be histochemically stained.

Thus, although ample evidence suggests an important role for acetylcholine in the insect FG, as yet the data do not distinguish between cholinergic synaptic transmission and cholinergic modulation.

\section{Neurosecretion and Neuromodulation in the Stomatogastric Nervous System}

The way by which the function of the nervous system is modified to allow an animal the behavioral plasticity needed to adapt to the changing demands of its environment is a fundamental question in neurobiology. Substantial progress has been made by studying rhythmic behaviors and the central pattern generator circuits that generate them $[114,115]$. It is now clear that the nervous system can alter the properties of central pattern generators, via both descending as well as sensory inputs, to elicit many different motor patterns [e.g. 22, 116-121]. Thus the motor patterns of the insect foregut are expected to be multiple and complex, and the FG central pattern generator controlling these motor patterns is expected to generate various motor outputs, depending on the animal's physiological and behavioral state.

\section{Neuromodulation of the Frontal Ganglion Central Pattern Generator}

As already described, the insect stomatogastric nervous system plays a major role in two behavioral contexts: feeding and molting. Both behaviors (especially the latter) 
Fig. 5. Simultaneous recordings from the median and posterior pharyngeal nerves (MPN and PPN, respectively) in a fully isolated locust FG in vitro. Data show the FG rhythm in control conditions, 5 and $10 \mathrm{~min}$ after bath application of $1 \mathrm{~m} M$ of paraoxon (PO). The organophosphorous compound PO inhibits the enzyme acetylcholinesterase irreversibly.

\section{Control}

MPN

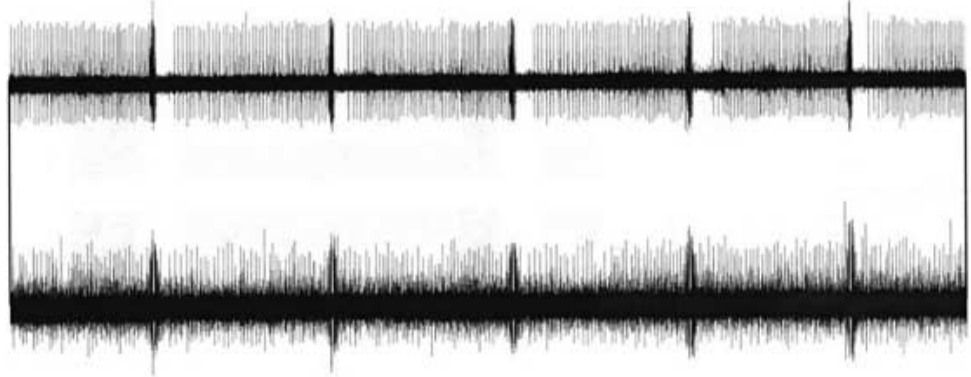

PPN

5 min after $P O$

MPN

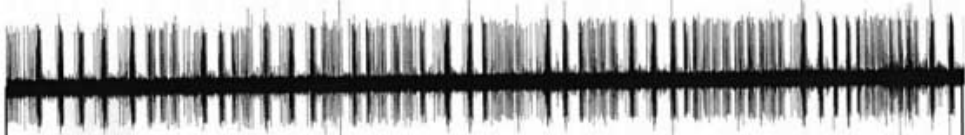

PPN

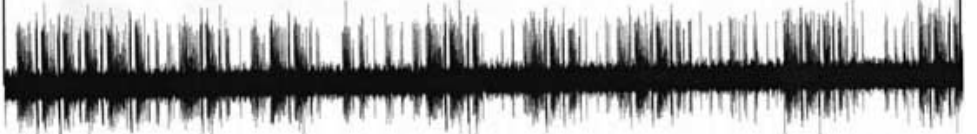

10 min after $P O$

MPN

PPN

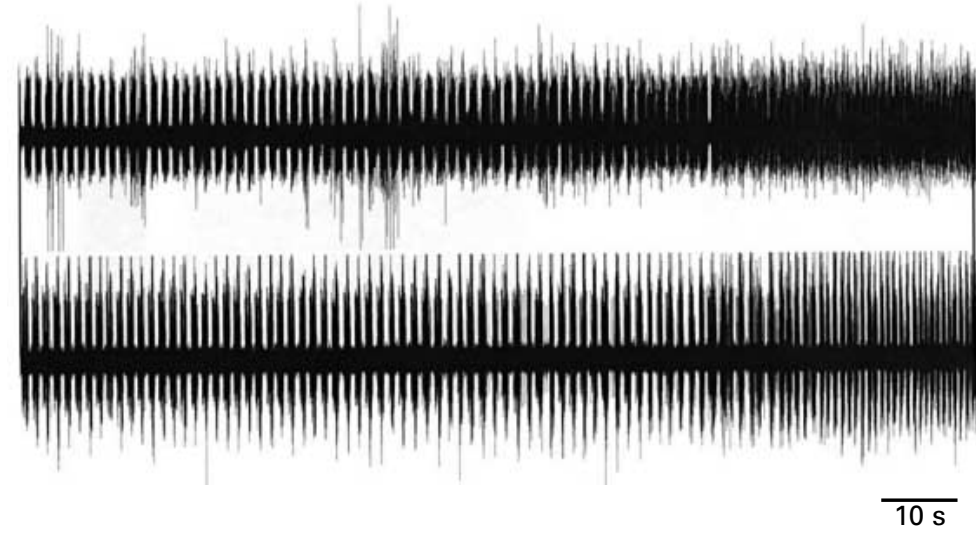

are made up of a complex set of motor patterns that need to be carefully coordinated and controlled.

Volumetric feedback from the gut has been suggested in several preparations and undoubtedly takes part in the control of the stomatogastric nervous system and feedingrelated motor output. Sensory information mediated via stretch receptors from the gut wall has been shown to be instrumental in the control of feeding in the fly [122-125]. Volumetric feedback from the crop and hindgut was reported to interact in the regulation of meal size in crickets [126] and locusts [127]. Clarke and Langley [13] reported that in L. migratoria, the FG forms a link in the passage of nervous impulses originating from the stretch receptors of the pharynx and passing via the posterior pharyngeal nerve, FG and frontal connectives to the brain. Consistent with these early reports [see also 20], Zilberstein and Ayali [46] found that the amount of food present in the locust gut modulates the frequency of the 
FG rhythm. The FG and foregut feeding-related rhythmic patterns were totally inhibited when the entire gut seemed replete with food [46]. In $M$. sexta the pattern of foregut activity has also been shown to vary with the amount of food present in the foregut and crop [48].

The ascending signals of gut sense organs (e.g. stretch receptors) could either produce inhibition directly or generate central inhibition [79]. Miles and Booker [48] showed that isolating the FG of Manduca larvae from the brain results in alteration of the FG rhythmic pattern. As reported for other insect central pattern generators [128], inputs from the brain were shown to have an inhibitory effect on the locust ganglion in an in vitro FG-brain preparation. The locust FG rhythmic pattern emerged only after severing the frontal connectives coming from the brain [46]. Other neuronal inputs to the FG have also been suggested. As already mentioned, Zilberstein and Ayali [47] reported on interactions between the FG and the thoracic ventilation central pattern generator, which are mediated via the frontal connectives. Backfilling the frontal connectives resulted in staining several neurons in the subesophageal ganglion and in thoracic ganglia all the way to the metathoracic ganglion, in which a single neural cell body was stained (Zilberstein and Ayali, unpublished finding). The metathoracic ganglion is where the locust ventilation central pattern generator resides [129].

Feeding-related motor patterns in the stomatogastric nervous system could also be controlled by humoral factors or regulatory neurohormones released into the circulation. These can be similar or different to those acting in classic synaptic transmission in the above-mentioned neuronal pathways. Release of humoral factors that play a role in cessation of locust feeding and involvement of chemoreceptors of the foregut was already suggested by Bernays and Chapman [130]. Ayali et al. [45] reported that application of hemolymph collected from locusts with a very full gut and crop to an isolated FG in vitro inhibits an ongoing rhythm.

Chemical modulation of FG motor patterns may also be working via localized release of neuromodulatory substances into the ganglion neuropil. In their electron microscopic and immunohistochemical study of the FG of $P$. americana, Ude et al. [131] reported a high content of neurosecretory material limited to the FG neuropil. These authors suggested that the autonomous control of the FG over vegetative function is influenced (i.e. modulated) by extrinsic neurosecretory cells establishing contact with intrinsic neurons within the ganglion. In $A$. domesticus, Kirby et al. [21] described neurons with cell bodies in the brain's median neurosecretory area that send their axons to the FG, and suggested that these neurons are the source of the neurosecretory material described by many authors in the FG [see references in 21].

Two candidates for feeding-related FG neuromodulation will be discussed below: first, peptides of the allatostatin peptidergic family, and second, the biogenic monoamine octopamine.

Allatostatins are a large group of neuropeptides identified and localized by immunocytochemical means in many different insect species [132-137]. Besides their original physiological role as inhibitors of juvenile hormone production, members of this rich family of peptides have been reported to demonstrate inhibition of myotropic activity [138, and references therein]. Maestro et al. [134] have observed allatostatin-immunoreactive neurons in the tritocerebrum of Blattella germanica, with axons projecting and branching into the FG. This is of great interest in the light of recent data by Zilberstein and Ayali [47], who reported modulatory effects of allatostatin on the rhythmic output of an isolated locust FG in vitro. Furthermore, as described in the next section, FG cells that contain allatostatin immunoreactivity have been reported in various insects. The question whether the FG network is auto-modulated by neurosecreting neurons from within the ganglion is very intriguing.

Octopamine is an important modulator of neural function and behavior in insects. Octopamine modulation of insect rhythmic behavior has been repeatedly described [e.g. 139, 140, 141]. In relation to feeding behavior, in a recent study Miles and Booker [142] suggested that the dramatic decline in foregut activity demonstrated by M. sexta larvae parasitized by the braconid wasp Cotesia congregata was due to a sharp increase in hemolymph octopamine. Octopamine may also be a modulator of feeding and gut motor patterns in normal healthy larval moths.

In accordance with the above report, application of octopamine to an isolated locust FG in vitro disrupted all rhythmic activity [47]. Braunig [143] reported on subesophageal, octopaminergic dorsal unpaired median neurons which project into the FG. The ganglion is reached via the frontal connectives. Additional axon collaterals project into the numerous side branches of the nervous corporis cardiaci III, which innervate the hypocerebral ganglion and several pharyngeal dilator muscles. Thus one can speculate that octopamine, which is often correlated with arousal state in insects [144-146] and plays an important role in locust flight [145, 147, 148], will work to inhibit feeding-related behavior during demanding and stressful physiological states. 
It is interesting to note that a role in the regulation of the stomatogastric nervous system was suggested for another biogenic amine, histamine. Horner et al. [149] reported that the histamine-immunoreactive terminals in the neuropil of the FG of G. bimaculatus have a neurosecretory appearance. This observation was also confirmed in the cockroach Leucophaea maderae [150].

The same mechanisms that act to shape feeding-related motor patterns in the insect stomatogastric nervous system also apply to the molt. Hughes [75] suggested a role for volumetric feedback in regulating the air-swallowing motor program during ecdysis. This was confirmed by Zilberstein and Ayali [46], who punctured the fully inflated gut of an adult locust when it was expanding its wings just as it fully emerged. A characteristic FG air swallowing rhythm was instantaneously initiated to compensate for loss of air pressure in the gut.

A number of peptide hormones are currently believed to be involved in the control of insect ecdysis behavior [151]. Carlson and O'Gara [76] reported that the cricket FG could generate spontaneous activity in vitro only if isolated from near-molt, ecdysing, or expanding insects. This state of 'activation' wore out within $1 \mathrm{~h}$, during which the ganglion generated an air-swallowing pattern. In Manduca there is also evidence for foregut and FG modulation during the molt: hemolymph collected from molting larvae and applied to a larval FG-foregut preparation altered the ongoing feeding motor pattern to resemble that observed in molting larvae. A rhythmic motor pattern that resembles air swallowing could be generated in isolated heads of animals 24-30 h from eclosion by application of eclosion hormone (EH) [49]. Interestingly, in the locust, hemolymph collected from non-feeding premolt larvae inhibited FG rhythmic activity [45], and Zilberstein and Ayali [47] have reported that eclosion hormone transiently inhibited the FG rhythmic pattern in vitro. These different and somewhat contradictory observations can be explained by considering the different and complex effects of the various insect ecdysis-related peptides [151-154], and by suggesting that exact timing is crucial for the experimental manipulations. Zitnan and Adams [155] suggest that the initiation of pre-ecdysis behavior and the transition to ecdysis are regulated by stimulatory and inhibitory factors released within the central nervous system (CNS) after the initial actions of preecdysis-triggering and ecdysis-triggering hormones. These factors, including EH, which is released both centrally into the brain and CNS and into the circulation, set the temporal organization of ecdysis behavior and the progression from one phase to the next. Thus, to activate each subunit of the molt set of programmed behaviors, specific neural elements, including the FG neural network(s), are targeted at precise time points.

According to the current scheme, crustacean cardioactive peptide (CCAP) plays a role in maintaining the ecdysis motor program in insects [151]. Bestman and Booker (pers. commun.) have observed that CCAP generated increased motility and, in many cases, peristalsis in the molting larvae foregut. In locusts, Zilbertstein and Ayali [47] demonstrated a modulatory effect of CCAP on the rhythmic pattern of the FG: a dose-dependent excitatory effect was obtained by application of CCAP to an isolated locust ganglion in vitro. In accordance with these reports, Dircksen and Homberg [156] observed CCAP immunoreactivity in locust brain neurons that gave rise to extensive arborization within the FG neuropil as well as in a FG neuron.

\section{The Insect Stomatogastric Nervous System and \\ Frontal Ganglion as a Source of Neurosecretion}

In contrast to the rather limited studies on other aspects of insect stomatogastric nervous system physiology, very rich literature is available on neuropeptides and other neurosecretory substances in cells of the stomatogastric system. Nevertheless, early reports regarding the presence of neurosecretory cells in the FG were somewhat controversial [10, and references therein].

Peptide-producing neurosecretory cells have been described in the FG of a number of lepidopterous insect species. Bounhiol et al. [157] described two such cells in Bombyx mori. This was supported by similar findings in Manduca [35, 36] and Diatraea grandiosella [158]. No specific role was suggested for these cells. Different degrees of activity in diapausing and non-diaposing pupae indicate a close relationship to developmental processes. Recently Duve et al. [135] reported on two pairs of large FG cells in Helicoverpa armigera that demonstrate allatostatin immunoreactivity, with one of the pairs showing colocalization with allatotropin [see also 137]. The axons of all four cells project to the brain via the frontal connectives and to the foregut via the recurrent nerve [136]. It is thus suggested that peptidergic neurons in the FG play a major role in regulating foregut motility ([135], see also previous section).

Penzlin [10] gave a thorough report of evidence for the presence of unidentified neurosecretory cells in the stomatogastric nervous system of different Orthoptera (mainly Periplaneta and locusts). A considerable amount of data regarding neurosecretory (mostly peptidergic) cells in the FG has accumulated since that review article was 
published. Cell bodies that show immunoreactivity to a myotropic neuropeptide, Lom-AG myotropin I were detected in the FG of L. migratoria [159]. Locustatachykinin I (another myotropic neuropeptide) immunoreactivity was also found in cells of the FG of the locust [160, 161]. Myoshi and Endo [162] investigated the FMRFamide-containing peptidergic neurons in the stomatogastric nervous system of the American cockroach by immunoelectron microscopy. Immunoreactive cell bodies were located in both the ingluvial and frontal ganglia.

Luffy and Dorn [163] reported the presence of seven pairs of serotonergic perikarya in the FG of Carausius morosus. These authors also reported a strong excitatory effect of 5-HT on the isolated midgut. This was also observed in Teleogryllus by Cooper and He [164]. In another cricket, G. bimaculatus, serotonin and other major biogenic amines (octopamine, dopamine) were reported to be synthesized and metabolized in the FG [165], where the amount of serotonin was found to be highest.

Thus insect FG neurons are an important source of neurosecretion. The neurosecretory material from the FG can modulate muscles of the alimentary canal, thus providing an additional route for the stomatogastric nervous system control of gut motor patterns in feeding- and molting-related behavior.

Finally, there is even evidence for the presence of insulin in the FG of M. sexta [166], though no specific role for this has yet been suggested.

\section{Concluding Remarks}

Studies of identified neurons in insects have provided unsurpassed data on neural mechanisms of behavior [4]. In order for the insect FG and stomatogastric preparation to reach its full potential, much more work is needed in identifying and characterizing members of the FG central pattern generator in Manduca and the locust (for which much information is already available), as well as in other insect preparations.

A comparative approach in future research is important in order to elucidate the physiological significance of the FG and stomatogastric nervous system in insect behavior. More specifically, comparative studies across different insect species as well as different developmental stages are needed. The FG of Lepidoptera consists of circa 35 neurons, while that of the Orthopteran insects features three times this number or even more. Comparing the neuronal composition of the FG (and other stomatogastric ganglia) between these groups will shed light on the role of the different components in generating and controlling behavior. Comparing the stomatogastric nervous system of the larval and adult stages in holometabolous insects is also an important question with implications for developmental neuroscience. Since the same set of neurons drive both the larval foregut and the adult cibarial pump, as neurons are neither added nor removed from the FG during adult development [49], it will be interesting to determine how the functions of the larval neurons change during adult development.

Finally, the question of motor program selection or the choice of motor pattern is fundamental in the study of the nervous system [167]. Hence, much of the appeal of the insect stomatogastric nervous system as a future neurobiological model system arises from its important dual role in feeding- and molting-related behavior. The specific motor output of defined neural circuits within the system must be generated at the appropriate time, in full coordination with other complex behavioral patterns. Hence, neuromodulation and the interaction between neural centers are fundamental concepts in understanding this system. Following the investigations described herein, comparing the feeding- and molting-related FG motor patterns, the way they are generated within the stomatogastric nervous system and the neural and chemical factors that shape and control them, is the mission we are currently engaged in. 


\section{References}

1 Hoyle G: Identified neurons and the future of neuroethology. J Exp Zool 1975;194:51-74.

2 Burrows M: The Neurobiology of an Insect Brain. Oxford, Oxford University Press, 1996.

3 Bassler U, Buschges A: Pattern generation for stick insect walking movements - multisensory control of a locomotor program. Brain Res Rev 1998;27:65-88.

4 Comer CM, Robertson RM: Identified nerve cells and insect behavior. Prog Neurobiol 2001; 63:409-439.

5 Boyan GS, Ball EE: The grasshopper, Drosophila and neuronal homology (advantages of the insect nervous system for the neuroscientist). Prog Neurobiol 1993;41:657-682.

6 Van Der Horst DJ: Insects as model systems for animal physiology. Neth J Zool 1994;44: 130-138.

7 Pearson KG: Common principles of motor control in vertebrates and invertebrates. Ann Rev Neurosci 1993;16:265-297.

8 Marder E: Non-mammalian models for studying neural development and function. Nature 2002;417:318-321.

9 Cazal P: Les glandes endocrines rétrocérébrales des insectes (étude morphologique). Bull Biol Fr Belg 1948;32(suppl):1-227.

10 Penzlin H: Stomatogastric nervous system; in Kerekut GA (ed): Comprehensive Insect Physiology, Biochemistry and Pharmacology. Oxford, Pergamon Press, 1985, pp 371-406.

11 Orlov J: Die Innervation des Darmes der Insekten (Larven von Lamelicorniern). Z Wiss Zool 1924;122:425-502.

12 Willey RB: The morphology of the stomodea nervous system in Periplaneta americana (L.) and other Blattaria. J Morphol 1961;108:219261.

13 Clarke KU, Langley PA: Studies on the initiation of growth and moulting in Locusta migratoria migratorioides $\mathrm{R}$ and F. 2. The role of the stomatogastric nervous system. J Insect Physiol 1963;9:363-373.

14 Clarke KU, Langley PA: Studies on the initiation of growth and moulting in Locusta migratoria migratorioides $\mathrm{R}$ and $\mathrm{F}$. 3. The role of the frontal ganglion. J Insect Physiol 1963;9:411421.

15 Clarke KU, Langley PA: Effect of removal of frontal ganglion on development of gonads in Locusta migratoria. Nature 1963;198:811812

16 Dando J, Chaussot B, Dando MR: Le systéme nerveux stomodéal post-cephalique de Schistocerca gregaria Forsk. (Orthoptére) et Blabera craniifer Burm. (Dictyoptére). C R Acad Sci Paris (D) 1968;267:1852-1855.

17 Chanussot F, Dando J, Moulins M, Laverack MS: Mise en évidence d'une amine biogène dans le système nerveux stomatogastrique des insectes: Étude histochimique et ultrastructurale. C R Acad Sci Paris (D) 1969;268:21012104
18 Allum RC: Surgical Interference with the Anterior Stomatogastric Nervous System and Its Effect upon Growth and Moulting in Locusta migratoria migratorioides $\mathrm{R}$ and $\mathrm{F}$. $\mathrm{PhD}$ thesis, University of Nottingham, 1973.

19 Aubele E, Klemm N: Origin, destination and mapping of tritocerebral neurons of locust. Cell Tissue Res 1977;178:199-219.

20 Kirby P, Beck R, Clarke KU: The stomatogastric nervous system of the house cricket Acheta domesticus L. 1. The anatomy of the system and the innervation of the gut. J Morphol 1984; 180:81-103.

21 Kirby P, Beck R, Clarke KU: The stomatogastric nervous system of the house cricket Acheta domesticus L. 2. Iontophoretic study of neuron anatomy. J Morphol 1984;180:105-124.

22 Harris-Warrick RM, Marder E, Selverston AI, Moulins M (ed): Dynamic Biological Networks: The Stomatogastric Nervous System. Cambridge, Mass., MIT Press, 1992.

23 Millott FLN: The visceral nervous system of the earthworm. 1. Nerves controlling the tone of the alimentary canal. Proc R Soc Lond B 1943;131;271-295.

24 Millott FLN: The visceral nervous system of the earthworm. 2. Evidence of chemical transmission and the action of sympatheticomimetic and arasympatheticomimetic drugs on the tone of the alimentary canal. Proc R Soc Lond B 1943;131;362-373.

25 Barna J, Csoknya M, Lazar Z, Bartho L, Hamori J, Elekes K: Distribution and action of some putative neurotransmitters in the stomatogastric nervous system of the earthworm, Eisenia fetida (Oligochaeta, Annelida). J Neurocytol 2001;30:313-325.

26 Barna J, Banyolgyi T, Csoknya M, Hamori J, Elekes K: The neurochemical organization of the stomatogastric nervous system in oligochaeta. Eur J Neurosci 1998;10:20226 (abstr.).

27 Jones JC: The anatomy and rhythmic activities of the alimentary canal of Anopheles larvae. Ann Ent Soc Am 1960;53:459-474.

28 Knight MR: Rhythmic activities of the alimentary canal of the black blowfly, Phormia regina Meig. Ann Ent Soc Am 1962;55:280-382.

29 Grenvile H: Anatomical and Physiological Studies on the Innervation of the Animentary Canal in Locusta migratoria migratorioides $\mathrm{R}$ and $\mathrm{F}$ and Schistocerca gregaria Forsk. PhD thesis, University of Nottingham, 1962.

30 Room RE: The Function of the Stomatogastric Nervous System as a Link between Feeding, Endocrine Secretion and Growth in Insects. PhD thesis, University of Nottingham, 1968.

31 Cook BJ, Eraker J, Anderson GR: The effect of various biogenic amines on the activity of the foregut of the cockroach Blaberus giganteus. J Insect Physiol 1969;15:445-455.

32 Mohl B: The control of foregut movements by the stomatogastric nervous system in the European house cricket Acheta domesticus L. J Comp Physiol 1972;80:1-28.

33 Snodgrass RE: Principles of Insect Morphology. Ithaca, Cornell University Press, 1993.
34 Orlov J: Über den histologischen Bau des Ganglions des Mund-Magennervensystems der Insekten. Z Mikroanat Forsch 1925;2:39-110.

35 Borg TK, Bell RA, Picard DJ: Ultrastructure of neurosecretory cells in the frontal ganglion of the tobacco hornworm, Manduca sexta (L). Tissue Cell 1973;5:259-267.

36 Bell RA, Borg TK, Ittycher PI: Neurosecretory cells in the frontal ganglion of the tobacco hornworm, Manduca sexta. J Insect Physiol 1974; 20:669-678.

37 Chapman RF: Structure of the digestive system; in Kerekut GA (ed): Comprehensive Insect Physiology Biochemistry and Pharmacology. Oxford, Pergamon Press, 1985, pp 165 205

38 Panov AA: Postcerebral endocrine organs and stomatogastric nervous system in imago of Ptychoptera contaminata, Ptychoptera scutellaris (Psychodomorpha), and Bibio marci (Bibionomorpha), (Diptera). Zool Zh 2000;79:186193.

39 Panov AA: Retrocerebral endocrine complex and postcerebral portion of the stomatogastric nervous system in 'higher' asilomorphous Diptera. Zool Zh 1999;78:456-465.

40 Panov AA: Retrocerebral endocrine complex and postcerebral portion of stomatogastric nervous system in lower Brachycera-Orthorrhapha. 3. Xylomyidae, Coenomyiidae, and Xylophagidae. Zool Zh 1998;77:1143-1151.

41 Boleli IC, Simoes ZLP, Hartfelder K: The stomatogastric nervous system of the honey bee (Apis mellifera) in a critical phase of caste development. J Morphol 1998;236:139-149.

42 Gundel M, Penzlin H: The neuronal connections of the frontal ganglion of the cockroach Periplaneta americana. Cell Tissue Res 1978; 193:353-371.

43 Ude J, Agricola H: Synaptic connections of the nervus connectivus in the frontal ganglion of Periplaneta americana (Insecta). An electron microscopic and iontophoretic study. Cell Tissue Res 1979;204:155-159.

44 Jagota A, Habibulla M: Neuronal maps of the frontal ganglion of the Cockroach, Periplaneta americana, prepared by heavy-metal iontophoresis. J Morphol 1992;213:287-294.

45 Ayali A, Zilberstein Y, Cohen N: The locust frontal ganglion: A central pattern generator network controlling foregut rhythmic motor patterns. J Exp Biol 2002;205:2825-2832.

46 Zilberstein Y, Ayali A: The role of the frontal ganglion in locust feeding and moulting-related behaviours. J Exp Biol 2002;205:2833-2841.

47 Zilberstein Y, Ayali A: Neuromodulation of the locust frontal ganglion central pattern generator. Abstr 15th Meet Am Soc Neurosci, Orlando, 2002.

48 Miles CI, Booker R: The role of the frontal ganglion in foregut movements of the moth, Manduca sexta. J Comp Physiol A 1994;174:755767.

49 Miles CI, Booker R: The role of the frontal ganglion in the feeding and eclosion behavior of the moth, Manduca sexta. J Exp Biol 1998;201: 1785-1798. 
50 Bestman JE, Booker R: Modulation of foregut synaptic activity controls resorption of molting fluid during larval molts of the moth Manduca sexta. J Exp Biol 2003;206:1207-1220.

51 Copenhaver PF, Taghert PH: Development of the enteric nervous system in the moth. 1. Diversity of cell types and the embryonic expression of FMRFAmide-related neuropeptides. Dev Biol 1989;131:70-84.

52 Copenhaver PF, Taghert PH: Development of the enteric nervous system in the moth. 2 . Stereotyped cell migration precedes the differentiation of embryonic neurons. Dev Biol 1989; 131:85-101.

53 Copenhaver PF, Taghert PH: Origins of the insect enteric nervous system: Differentiation of the enteric ganglia from a neurogenic epithelium. Development 1991;113:1115-1132.

54 Copenhaver PF, Taghert PH: Neurogenesis in the insect enteric nervous-system: Generation of premigratory neurons from an epithelial placode. Development 1990;109:17-28.

55 Copenhaver PF: Origins, migration and differentiation of glial cells in the insect enteric nervous system from a discrete set of glial precursors. Development 1993;117:59-74.

56 Hartensein V, Tepass U, Gruszynskidefeo E: Embryonic development of the stomatogastric nervous system in Drosophila. J Comp Neurol 1994;350:367-381.

57 Forjanic JP, Chen CK, Jackle H, Gaitan MG: Genetic analysis of stomatogastric nervous system development in Drosophila using enhancer trap lines. Dev Biol 1997;186:139-154.

58 Gonzalez-Gaitan M, Jackle H: Tip cell-derived RTK signaling initiates cell movements in the Drosophila stomatogastric nervous system anlage. EMBO Rep 2000;1:366-371.

59 Ganfornina MD, Sanchez D, Bastiani MJ: Embryonic development of the enteric nervous system of the grasshopper Schistocerca americana. J Comp Neurol 1996;372:581-596.

60 Hartenstein V: Development of the insect stomatogastric nervous system. Trends Neurosci 1997;20:421-427.

61 Faivre E: Expériences sur le rôle du cerveau dans l'ingestion des aliments chez les insectes, et sur les fonctions du ganglion frontal. CR Soc Biol Paris 1863;5:101-104.

62 Marchal P: Dictionnaire de Physiologie de Charles Richet. Paris, 1911, p 273.

63 Roussel JP: Role of the frontal ganglion on cardiac rhythm in Locusta migratoria L. Experientia 1972;29:804-805 [in French].

64 Ai H, Kuwasawa K: Neural pathways for cardiac reflexes triggered by external mechanical stimuli in larvae of Bombyx mori. J Insect Physiol 1995;41:1119-1131.

65 Kuwasawa K, Ai H, Matsushita T: Cardiac reflexes and their neural pathways in lepidopterous insects. Comp Biochem Physiol A 1999; 124:581-586.

66 Bounhiol J: Rôle possible du ganglion frontal dans la métamorphose de Bombyx mori L. CR Acad Sci Paris 1938;206:773-774.

67 Highnam KC, Hill L, Mordue W: The endocrine system and oocyte growth in Schistocerca in relation to starvation and frontal ganglionectomy. J Insect Physiol 1966;12:977-994.
68 Roussel JP: Contribution a l'étude du rôle du ganglion frontal chez les insectes. Bill Soc Zool Fr 1966;91:379-391.

69 Hill L, Mordue W, Highnam KC: Endocrine system frontal ganglion and feeding during maturation in the female desert locust. $\mathrm{J}$ Insect Physiol 1966;12:1197-1208.

70 Hill L, Mordue W, Highnam KC: Effects of starvation and extirpation of frontal ganglion upon certain metabolic processes in desert locust. Gen Comp Endocrinol 1965;5:685.

71 Penzlin H: Zur Rolle des Frontalganglions bei Larven der Schabe Periplaneta americana. J Insect Physiol 1971;17:559-573.

72 Bignell DE: The effect of removal of the frontal ganglion on growth and protein synthesis in young adults of Locusta migratoria. Can J Zool 1973;52:203-208.

73 Verrett JM, Mills RR: Water-balance during vitellogenesis by the American cockroach: Effect of frontal ganglionectomy. J Insect Physiol 1976;22:251-257.

74 Hughes TD: Physiological Studies of Ecdysis in Locusts. PhD thesis, University of Oxford, 1978.

75 Hughes TD: The imaginal ecdysis of the desert locust, Schistocerca gregaria. 4 . The role of the gut. Physiol Entomol 1980;5:153-164.

76 Carlson JR, O'Gara BA: The ecdysis of the cricket, Teleogryllus oceanicus: Generation of the pharyngeal air-swallowing motor program by the isolated frontal ganglion. Comp Biochem Physiol A 1983;75:579-587.

77 Bell RA: Role of the frontal ganglion in lepidopterous insects; in Borkovec AB (ed): Insect Neurochemistry and Neurophysiology. New York, Plenum Press, 1983, pp 321-324.

78 Bushman DW, Nelson JO: The role of the frontal ganglion and corpora cardiaca-corpora allata complex in post-feeding weight loss in adult Heliothis zea. Physiol Entomol 1990;15:269_ 274.

79 Griss C, Simpson SJ, Rohrbacher J, Rowell CHF: Localization in the central nervous system of larval Manduca sexta (Lepidoptera, Sphingidae) of areas responsible for aspects of feeding behavior. J Insect Physiol 1991;37: 477-482.

80 Timmins WA, Reynolds SE: Physiological mechanisms underlying the control of meal size in Manduca sexta larvae. Physiol Entomol 1992;17:81-89.

81 Davey KG, Treherne JE: Studies on crop function in the cockroach (Periplaneta americana L). 1. Mechanism of crop emptying. J Exp Biol 1963;40:763-774.

82 Davey KG, Treherne JE: Studies on crop function in the cockroach (Periplaneta americana L). 2. Nervous control of crop emptying. J Exp Biol 1963;40:775-780.

83 Carlson JR: The imaginal ecdysis of the cricket Teleogryllus oceanicus. 1. Organization of motor programs and roles of central and sensory control. J Comp Physiol A 1977;115:299-317.

84 Carlson JR: The imaginal ecdysis of the cricket Teleogryllus oceanicus. 2. The roles of identified motor units. J Comp Physiol A 1977;115: 319-336.
85 Hughes TD: The imaginal ecdysis of the desert locust, Schistocerca gregaria. 2. Motor activity underlying the pre-emergence and emergence behaviour. Physiol Entomol 1980; 5:55-71.

86 Hughes TD: The imaginal ecdysis of the desert locust, Schistocerca gregaria. 3. Motor activity underlying the expansional and postexpansional behaviour. Physiol Entomol 1980;5:141-152.

87 Hughes TD: The imaginal ecdysis of the desert locust, Schistocerca gregaria. 1. A description of the behaviour. Physiol Entomol 1980;5:47-54.

88 Reynolds SE: integration of behaviour and physiology in ecdysis. Adv Insect Physiol 1980;15:475-595.

89 Truman JW, Endo PT: Physiology of insect ecdysis: Neural and hormonal factors involved in wing-spreading behaviour of moths. J Exp Biol 1974;61:47-55.

90 Weeks JC, Truman JW: Neural organization of peptide-activated ecdysis behaviors during the metamorphosis of Manduca sexta. J Comp Physiol A 1984;155:407-422.

91 Miles CI, Weeks JC: Developmental attenuation of the pre-ecdysis motor pattern in the tobacco hornworm, Manduca sexta. J Comp Physiol A 1991;168:179-190.

92 Dominick OS, Truman JW: The physiology of wandering behavior in Manduca sexta. 3 . Organization of wandering behavior in the larval nervous system. J Exp Biol 1986;121: 115-132.

93 De Bellesme J: Phénomènes qui accompagnent la métamorphose chez la Libellule déprimée. CR Acad Sc Paris 1877;85:448-450.

94 Cottrell CB: The imaginal ecdysis of blowflies. Observations on the hydrostatic mechanisms involved in digging and expansion. $\mathrm{J}$ Exp Biol 1962;39:431-448.

95 Elliot CJH: Neurophysiological Analysis of Locust Behaviour during Ecdysis. PhD thesis, University of Oxford, 1980.

96 Cornell JC, Pan ML: The disappearance of molting fluid in the tobacco hornworm, Manduca sexta. J Exp Biol 1983;107:501-504.

97 Passano LM: Molting and its control; in Waterman TH (ed): Physiology of Crustacea. New York, Academic Press, 1960, vol 1, pp 473-535.

98 Dall W, Smith DM: Water uptake at ecdysis in western rock lobster. J Exp Mar Biol Ecol 1978;35:165-176.

99 Chung JS, Dircksen H, Webster SG: A remarkable, precisely timed release of hyperglycemic hormone from endocrine cells in the gut is associated with ecdysis in the crab Carcinus maenas. Proc Nat Acad Sci USA 1999; 96:13103-13107.

100 Phlippen MK, Webster SG, Chung JS Dircksen H: Ecdysis of decapod crustaceans is associated with a dramatic release of crustacean cardioactive peptide into the haemolymph. J Exp Biol 2000;203:521-536.

101 Hertel W: Elektrophysiologische Untersuchungen am stomatogastrischen Nervensystem von Periplaneta americana L. Zool Jahrb Physiol 1978;82:35-44. 
102 Hertel W, Koch J, Penzlin H: Elektrophysiologische Untersuchungen am Frontaganglion von Periplaneta americana L. J Insect Physiol 1978;24:721-735.

103 Pandey A, Habibulla M: Circadian rhythms of serotonin and the electrical activity of the frontal ganglion of the cockroach, Periplaneta americana. Experientia 1982;38:946-948.

104 Hertel W, Penzlin H: Untersuchungen zur spontanen rhythmischen Aktivität im stomatogastrischen Nervensystem von Periplaneta americana L. (Blattaria). Zool Jahrb Physiol 1982;86:272-290.

105 Sarll D: Feeding Activity and the Stomatogastric Nervous System in Locusta migratoria L. PhD thesis, University of Bristol, 1971.

106 Ude J, Eckert M, Penzlin H: The frontal ganglion of Periplaneta americana L. (Insecta). Cell Tissue Res 1978;191:171-182.

107 Marder E, Bucher D: Central pattern generators and the control of rhythmic movements. Curr Biol 2001;11:R986-R996.

108 Shefi O, Ben Jacob E, Ayali A: Growth morphology of two-dimensional insect neural networks. Neurocomputing 2002;44:635-643.

109 Hertel W, Reinhardt R: Wirkung einiger phosphororganischer insektizider Substanzen auf die Spontanaktivität des Nervus connectivus des Frontalganglions von Periplaneta americana L. Zool Jahrb Physiol 1981;85: 304-311.

110 Hertel W, Wuttig U, Reinhard R, Penzlin H: Effects of organo-phosphorous insecticides by frontal ganglion test of Periplaneta americana (L) in vitro. Zool Jahrb Physiol 1985;89:257264.

111 Marder E: Cholinergic motor neurons in the stomatogastric system of the lobster. J Physiol 1976;257:63-86

112 Marder E: Acetylcholine as an excitatory neuromuscular transmitter in the stomatogastric system of the lobster. Nature 1974;251:730731.

113 Tazaki K, Chiba C: Glutamate, acetylcholine, and gamma-aminobutyric-acid as transmitters in the pyloric system of the stomatogastric ganglion of a stomatopod, Squilla oratoria. J Comp Physiol A 1994;175:487-504.

114 Delcomyn F: Neural basis of rhythmic behavior in animals. Science 1980;210:492-498.

115 Stein SG, Grillner S, Selverston AI, Stuart DG (eds): Neurons, Networks, and Motor Behavior. Cambridge, Mass., MIT Press, 1997.

116 Harris-Warrick RM, Marder E: Modulation of neural networks for behavior. Ann Rey Neurosci 1991;14:39-57.

117 Grillner S, El Manira A, Tegner J, Wadden T, Vinay L, Barthe J-Y: Dynamic changes in functional connectivity in a lower vertebrate model; in Selverston AI, Ascher P (eds): Cellular and Molecular Mechanisms Underlying Higher Neural Functions. New York, John Wiley \& Sons, 1994, pp 127-147.

118 Harris-Warrick RM: Modulation of small neural networks in the crustacean stomatogastric ganglion; in Selverston AI, Ascher P (eds): Cellular and Molecular Mechanisms Underlying Higher Neural Functions. New York, John Wiley \& Sons, 1994, pp 111-126.
119 Marder E: Invertebrate neurobiology. Polymorphic neural networks. Curr Biol 1994;4: 752-754

120 Arshavsky YI, Deliagina TG, Orlovsky GN: Pattern generation. Curr Opin Neurobiol 1997; 7:781-789.

121 Ayali A, Harris-Warrick RM: Monoamine control of the pacemaker kernel and cycle frequency in the lobster pyloric network. J Neurosci 1999; 19:6712-6722.

122 Dethier VG, Bodenstein D: Hunger in the blowfly. Z Tierpsychol 1958;15:129-140.

123 Dethier VG, Galperin A: Hyperphagia in the blowfly. J Exp Biol 1967;47:191-200.

124 Gelperin A: Neural control systems underlying insect feeding behavior. Am Zool 1972; 12:489-496.

125 Rice MJ: Cibarial stretch receptors in the tsetse fly (Glossina austeni) and the blowfly (Calliphora erythrocephala). J Insect Physiol 1970;16:277-289.

126 Mohl B: Neurons in esophageal region of crickets and their possible function. Experientia 1969;25:947.

127 Simpson SJ: The role of volumetric feedback from the hindgut in the regulation of meal size in fifth-instar Locusta migratoria nymphs. Physiol Entomol 1983;8:451-467.

128 Thompson KJ: Oviposition digging in the grasshopper. 1. Functional anatomy and the motor programme. J Exp Biol 1986;122:387411.

129 Bustami HP, Hustert R: Typical ventilatory pattern of the intact locust is produced by the isolated CNS. J Insect Physiol 2000;46:12851293.

130 Bernays EA, Chapman RF: The regulation of feeding in Locusta migratoria: Internal inhibitory mechanisms. Entomol Exp Applic 1973; 16:329-342.

131 Ude J, Eckert M, Penzlin H: Frontal ganglion of Periplaneta-americana L (Insecta): An electron microscopic and immunohistochemical study. Cell Tissue Res 1978;191:171-182.

132 Duve H, Thorpe A: Distribution and functional significance of Leu-callatostatins in the blowfly Calliphora vomitoria. Cell Tissue Res 1994;276:367-379.

133 Duve H, Wren P, Thorpe A: Innervation of the foregut of the cockroach Leucophaea maderae and inhibition of spontaneous contractile activity by callatostatine neuropeptides. Physiol Entomol 1995;20:33-44.

134 Maestro JL, Belles X, Piulachs MD, Thorpe A, Duve H: Localization of allatostatin-immunoreactive material in the central nervous system, stomatogastric nervous system and gut of the cockroach Blattella germanica. Arch Insect Biochem Physiol 1998;37:269282.

135 Duve H, East PD, Thorpe A: Regulation of lepidopteran foregut movement by allatostatins and allatotropin from the frontal ganglion. J Comp Neurol 1999;413:405-416.
136 Duve H, Audsley N, Weaver RJ, Thorpe A: Triple co-localisation of two types of allatostatin and an allatotropin in the frontal ganglion of the lepidopteran Lacanobia oleracea (Noctuidae): Innervation and action on the foregut. Cell Tissue Res 2000;300:153-163.

137 Duve H, Thorpe A: Neuropeptide co-localisation in the lepidopteran frontal ganglion studied by confocal laser scanning microscopy. Cell Tissue Res 2003;311:79-89.

138 Gade G: Allatoregulatory peptides: Molecules with multiple functions. Invertebr Reprod Dev 2002;41:127-135.

139 Sombati S, Hoyle G: Generation of specific behaviors in a locust by local release into neuropil of the natural neuromodulator octopamine. J Neurobiol 1984;15:481-506.

140 Ramirez JM, Orchard I: Octopaminergic modulation of the forewing stretch receptor in the locust Locusta migratoria. J Exp Biol 1990;149:255-279.

141 Roeder T: Octopamine in invertebrates. Prog Neurobiol 1999;59:533-561.

142 Miles CI, Booker R: Octopamine mimics the effects of parasitism on the foregut of the tobacco hornworm Manduca sexta. J Exp Biol 2000;203:1689-1700.

143 Braunig P: The peripheral branching pattern of identified dorsal unpaired median (DUM) neurones of the locust. Cell Tissue Res 1997; 290:641-654.

144 Davenport AP, Evans PD: Changes in haemolymph octopamine levels associated with food deprivation in the locust, Schistocerca gregaria. Physiol Entomol 1984;9:269-274.

145 Parker D: Octopaminergic modulation of locust motor neurones. J Comp Physiol A 1996; 178:243-252.

146 Stevenson PA, Hofmann HA, Schoch K, Schildberger K: The fight and flight responses of crickets depleted of biogenic amines. J Neurobiol 2000;43:107-120.

147 Orchard I, Ramirez JM, Lange AB: A multifunctional role for octopamine in locust flight. Ann Rev Entomol 1993;38:227-249.

148 Pfluger HJ, Duch C: The functional role of octopaminergic neurons in insect motor behavior. Acta Biol Hung 2000;51:343-348.

149 Hörner M, Helle J, Schürmann F-W: The distribution of histamine-immunoreactive neurons in the ventral nerve cord of the cricket, Gryllus bimaculatus. Cell Tissue Res 1996; 286:393-405.

150 Nässel DR: Histamine in the brain of insects: A review. Microsc Res Tech 1999;44:121136

151 Truman JW, Gammie SC, McNabb S: Role of neuroendocrine cascades in orchestrating complex behavioral programs in insects; in Eisner N (ed): Neuroethology on the Move. Stuttgart, Georg Thieme, 1997, pp 65-85.

152 Zitnan D, Kingan TG, Hermesman JL, Adams ME: Identification of ecdysis-triggering hormone from an epitracheal endocrine system. Science 1996;271:88-91.

153 Hesterlee S, Morton DB: Insect physiology: The emerging story of ecdysis. Curr Biol 1996;6:648-650. 
154 Kingan TG, Gray W, Zitnan D, Adams ME: Regulation of ecdysis-triggering hormone release by eclosion hormone. J Exp Biol 1997; 200:3245-3256.

155 Zitnan D, Adams ME: Excitatory and inhibitory roles of central ganglia in initiation of the insect ecdysis behavioural sequence. J Exp Biol 2000;203:1329-1340.

156 Dircksen H, Homberg U: Crustacean cardioactive peptide-immunoreactive neurons innervating brain neuropils, retrocerebral complex and stomatogastric nervous system of the locust, Locusta migratoria. Cell Tissue Res 1995;279:495-515.

157 Bounhiol JJ, Gabe M, Arvy L: Données histophysiologiques sur la neurosécrétion chez Bombyx mori $\mathrm{L}$ et sur les rapports avec les glandes endocrines. Bull Biol Fr Belg 1953; 87:323-333.

158 Yin CM, Chippendale GM: Insect frontal ganglion: Fine-structure of its neurosecretory cells in diapause and non-diapause larvae of Diatraea grandiosella. Can J Zool 1975;53: 1093-1100.
159 Paemen L, Schoofs L, De Loof A: Localization of Lom-Ag-myotropin I-like substances in the male reproductive and nervous tissue of the locust, Locusta migratoria. Cell Tissue Res 1992;268:91-97.

160 Nassel DR: Neuropepties in the insect brain: A review. Cell Tissue Res 1993;273:1-29.

161 Muren JE, Lundquist CT, Nassel DR: Abundant distribution of locustatachykinin-like peptide in the nervous-system and intestine of the cockroach Leucophaea maderae. Philos Trans R Soc Lond B Biol Sci 1995;348:423444.

162 Miyoshi T, Endo Y: Immunohistochemical study on peptidergic neurons containing FMRFamide in the stomatogastric nervous system of the American cockroach. Appl Entomol Zool 1998;33:133-138.
163 Luffy D, Dorn A: Serotoninergic elements in the stomatogastric nervous system of the stick insect, Carausius-morosus, demonstrated by immunohistochemistry. J Insect Physiol 1991;37:269-278.

164 Cooper PD, He PH: Control of foregut contractions in the black field cricket, Teleogryllus commodus Walker (Gryllidae, Orthoptera). J Insect Physiol 1994;40:475-481.

165 Iba M, Nagao T, Urano A: The levels of biogenic amines in the corpora allata, corpora cardiaca and frontal ganglion in the cricket, Gryllus bimaculatus. Zool Sci 1996;13:213217.

166 Elsalhy M, Falkmer S, Kramer KJ, Speirs $\mathrm{RD}$ : Immunocytochemical evidence for the occurrence of insulin in the frontal ganglion of a lepidopteran insect, the tobacco hornworm moth Manduca-sexta L. Gen Comp Endocrinol 1984;54:85-88.

167 Kupfermann I, Weiss KR: Motor program selections in simple model systems. Curr Opin Neurobiol 2001;11:673-677. 